Journal homepage: http://www.journalijar.com
Journal DOI: 10.21474/IJAR01

RESEARCH ARTICLE
INTERNATIONAL JOURNAL

OF ADVANCED RESEARCH

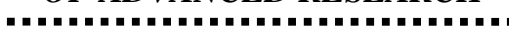

\title{
STUDIES ON THE MODE OF PLANTATION OF MULBERRY FOR SILKWORM REARING.
}

\author{
"Nirmal Singh ${ }^{1}$, J.S. Tara ${ }^{2}$, Sapna Rajput ${ }^{1}$, Suraksha Chanotra ${ }^{1}$, Rakhi Gupta ${ }^{1}$, Mohd. Bashir ${ }^{1}$, Ishfaq \\ Ahmed Dar ${ }^{1}$, Neetu Dhar ${ }^{1}$ and Rajat Mohan ${ }^{3}$. \\ 1. P.G. Department of sericulture, Poonch Campus, University of Jammu. \\ 2. Department of Zoology, University of Jammu. \\ 3. Regional Sericulture Research Station, Miran Sahib, Jammu.
}

\section{Manuscript Info}

Manuscript History:

Received: 14 April 2016

Final Accepted: 26 May 2016

Published Online: June 2016

Key words:

Bombyx mori, Mulberry plantation,

TR-10 cocoon yield, Shell ratio,

cocoon weight, filament length, spring season.

*Corresponding Author

Nirmal Singh.

\section{Abstract}

The present study was conducted to evaluate the plantation system of mulberry suitable for larval growth of silkworm, which ultimately influences the cocoon traits such as cocoon yield, cocoon weight, shell weight, silk percentage etc. Three plantation systems namely TR-10 bush, TR-10 cultivated tree and wild tree of same age were selected to feed on the ruling silkworm hybrid of Jammu SH6 $\times$ NB4D2 during the spring season to find out the varietal influence on silkworm hybrid.

Three replications each containing 250 larvae were retained after $3^{\text {rd }}$ instar. Different larval and cocoon parameters are recorded. From the results obtained, it is evident that the cultivated TR-10 tree should be grown for sericulture purpose in Jammu region.

\section{Introduction:-}

Mulberry is perennial, deciduous, deep rooted, fast growing and high biomass producing plant. Mulberry silk is known to be the most luxurious, elegant, tender and soft yarn in nature. The quantity and quality of the silk is directly proportional to the quality of mulberry leaves fed to the silkworm larvae thereby positively affecting the overall cocoon production. The nutritional quality of mulberry leaves play an important role in the nutrition of silkworm and in turn cocoon/ silk production (Choudhary et al., 1991; Krishnaswami, 1978; Liaw, 1991; Gowade and Mendhe, 2010). For a successful silkworm crop, the first important step is to select the excellent variety of the mulberry. The selection of variety for cultivation should be made by carefully considering the suitability of the plant to the existing weather conditions.

Machii and Katagiri (1991) emphasized that the duration of larval development of Bombyx mori L. differs with the mulberry varieties. Different factors responsible for successful rearing are as under:

$\begin{array}{ll}\text { Mulberry leaf } & : 38.2 \% \\ \text { Climate } & : 37.5 \% \\ \text { Rearing technique } & : 9.1 \% \\ \text { Silkworm race } & : 4.1 \% \\ \text { Other factors } & : 11.2 \%\end{array}$

Quality of mulberry leaves alone contributes $38.20 \%$ for quality cocoon production (Miyashita, 1986). Keeping in view, the above mentioned importance the current study was designed to investigate the varietal influence of mulberry on silkworm rearing and cocoon yield in Jammu region. 


\section{Material and methods:-}

The present study was carried out to see the impact of feeding three different mulberry plantation systems TR-10 bush, TR-10 cultivated and wild tree on the post cocoon parameters of the ruling silkworm hybrid of Jammu SH6XNB4D2 during the spring rearing (March- April) of 2015 in the RSRS, Miran Sahib, Jammu.

This was taken up to find out the various parameters and suitability of these different types of planting systems to silkworm feeding for cocoon production. The silkworms were fed on leaves of TR-10 bush, TR-10 cultivated tree and wild tree. Three replications each containing 250 larvae were retained after $3^{\text {rd }}$ instar. Silkworms were provided with four feedings per day. Fully mature larvae were transferred to the plastic collapsible mountages. The effect of different mulberry varieties were assessed based on the following parameters; pupation percentage, cocoon weight, shell weight, cocoon shell ratio, cocoon yield, filament length, denier, non breakable filament length etc.

\section{Result and discussion:-}

It is well known fact that the quality of mulberry leaves differs among mulberry varieties and specific components of the mulberry leaves are responsible for the difference in rearing performances of the silkworm (Aruga, 1994; Machii and Katagiri, 1990; Minamizawa, 1997; Sarkar and Fujita, 1994). The quality of mulberry leaves directly influences the cocoon quality and production. Thangamani and Vivekanandan (1984) reported the significant varietal influence of different mulberry genotypes onto the growth and development of silkworms and cocoon production. In the present investigation effect of three different plantation systems was seen on the ruling silkworm hybrid of Jammu region i.e. SH6 X NB4D2. The various results obtained by rearing SH6 X NB4D2 are shown in Table 1 and 2.

By analyzing the Table 1. Which shows that the number and weight of good cocoons was found to be highest in silkworms fed with TR-10 cultivated tree (317.06) followed by Wild tree (273.44) and TR-10 bush tree (245.22).

Table 1:- Table showing details of defective and good cocoons number and weight.

\begin{tabular}{|c|c|c|c|c|c|c|c|c|c|c|c|c|}
\hline \multirow[t]{2}{*}{$\begin{array}{l}\text { S.N } \\
\text { O }\end{array}$} & \multirow[t]{2}{*}{ Replication } & \multirow[t]{2}{*}{ Race } & \multicolumn{2}{|c|}{$\begin{array}{l}\text { Double } \\
\text { cocoons }\end{array}$} & \multicolumn{2}{|c|}{$\begin{array}{l}\text { Flimsy } \\
\text { cocoons }\end{array}$} & \multicolumn{2}{|c|}{$\begin{array}{c}\text { Malformed } \\
\text { cocoons }\end{array}$} & \multicolumn{2}{|c|}{$\begin{array}{l}\text { Urinated } \\
\text { cocoons }\end{array}$} & \multicolumn{2}{|c|}{ Good cocoons } \\
\hline & & & $\begin{array}{l}\text { Num } \\
\text { ber }\end{array}$ & $\begin{array}{l}\text { Wei } \\
\text { ght }\end{array}$ & $\begin{array}{l}\text { Num } \\
\text { ber }\end{array}$ & $\begin{array}{l}\text { Wei } \\
\text { ght }\end{array}$ & $\begin{array}{l}\text { Num } \\
\text { ber }\end{array}$ & $\begin{array}{l}\text { Wei } \\
\text { ght }\end{array}$ & $\begin{array}{l}\text { Num } \\
\text { ber }\end{array}$ & $\begin{array}{l}\text { Wei } \\
\text { ght }\end{array}$ & $\begin{array}{l}\text { Num } \\
\text { ber }\end{array}$ & $\begin{array}{l}\text { Wei } \\
\text { ght }\end{array}$ \\
\hline 1 & $\begin{array}{l}\text { TR-10 } \\
\text { BUSH }\end{array}$ & $\begin{array}{l}\text { SH6×N } \\
\text { B4D2 }\end{array}$ & 2.66 & 11.3 & 8 & $\begin{array}{c}11.2 \\
5\end{array}$ & 11.66 & $\begin{array}{c}18.2 \\
5\end{array}$ & 23 & $\begin{array}{c}38.9 \\
1\end{array}$ & $\begin{array}{c}145.3 \\
3\end{array}$ & $\begin{array}{c}245 . \\
22\end{array}$ \\
\hline 2 & $\begin{array}{l}\text { TR-10 } \\
\text { CULTIVAT } \\
\text { ED TREE }\end{array}$ & $\begin{array}{l}\text { SH6×N } \\
\text { B4D2 }\end{array}$ & 5 & $\begin{array}{c}16.9 \\
1\end{array}$ & 9 & $\begin{array}{c}15.2 \\
5\end{array}$ & 12.33 & $\begin{array}{c}16.1 \\
9\end{array}$ & 29.66 & $\begin{array}{c}47.6 \\
9\end{array}$ & $\begin{array}{c}190.6 \\
6\end{array}$ & $\begin{array}{c}317 . \\
06\end{array}$ \\
\hline 3 & $\begin{array}{l}\text { WILD } \\
\text { TREE }\end{array}$ & $\begin{array}{l}\text { SH6xN } \\
\text { B4D2 }\end{array}$ & 4 & $\begin{array}{c}13.2 \\
5\end{array}$ & 17 & $\begin{array}{c}29.0 \\
2\end{array}$ & 6 & $\begin{array}{c}16.1 \\
9\end{array}$ & 18 & $\begin{array}{c}32.1 \\
8\end{array}$ & $\begin{array}{c}159.3 \\
3\end{array}$ & $\begin{array}{c}273 . \\
44\end{array}$ \\
\hline
\end{tabular}

In general the average values of various post cocoon parameters like single cocoon weight, shell weight, filament length, non breakable filament length etc. were found to be higher in silkworms fed with TR-10 Cultivated tree, followed by TR-10 Bush and wild tree (Table2).

Table2:- Average table showing Assessment Report of Average cocoon weight, Average cocoon shell weight, filament length, non breakable filament length and denier.

\begin{tabular}{|l|l|l|l|l|l|l|l|}
\hline $\begin{array}{l}\text { S. } \\
\text { No. }\end{array}$ & Race & Replication & $\begin{array}{l}\text { Av wt } \\
\text { of } \\
\text { single } \\
\text { cocoon } \\
\text { (gm) }\end{array}$ & $\begin{array}{l}\text { Wt of } \\
\text { single } \\
\text { cocoon } \\
\text { shell }(\mathbf{g m})\end{array}$ & $\begin{array}{l}\text { Filament length } \\
\text { (06 cocoons } \\
\text { (avg) in meter. }\end{array}$ & $\begin{array}{l}\text { Non breakable } \\
\text { length }(\mathbf{0 6} \\
\text { cocoons) avg in } \\
\text { meter. }\end{array}$ & $\begin{array}{l}\text { Denier(06 } \\
\text { cocoons } \\
\text { avg) }\end{array}$ \\
\hline 1. & SH6×NB4D2 & TR-10 BUSH & 1.72 & 0.29 & 680 & 567.33 & 2.68 \\
\hline 2. & SH6×NB4D2 & $\begin{array}{l}\text { TR-10 } \\
\text { CULTIVATED } \\
\text { TREE }\end{array}$ & 1.72 & 0.30 & 770.66 & 611 & 2.66 \\
\hline 3. & SH6×NB4D2 & WILD TREE & 1.69 & 0.29 & 670.66 & 530.66 & 2.68 \\
\hline
\end{tabular}


Pupation percentage was found to be highest in silkworms fed with TR-10 cultivated tree followed by TR-10 bush and wild tree (Fig.1). The highest shell ratio percentage was observed from cocoons produced by larvae fed on TR10 cultivated tree than TR-10 bush and wild tree.
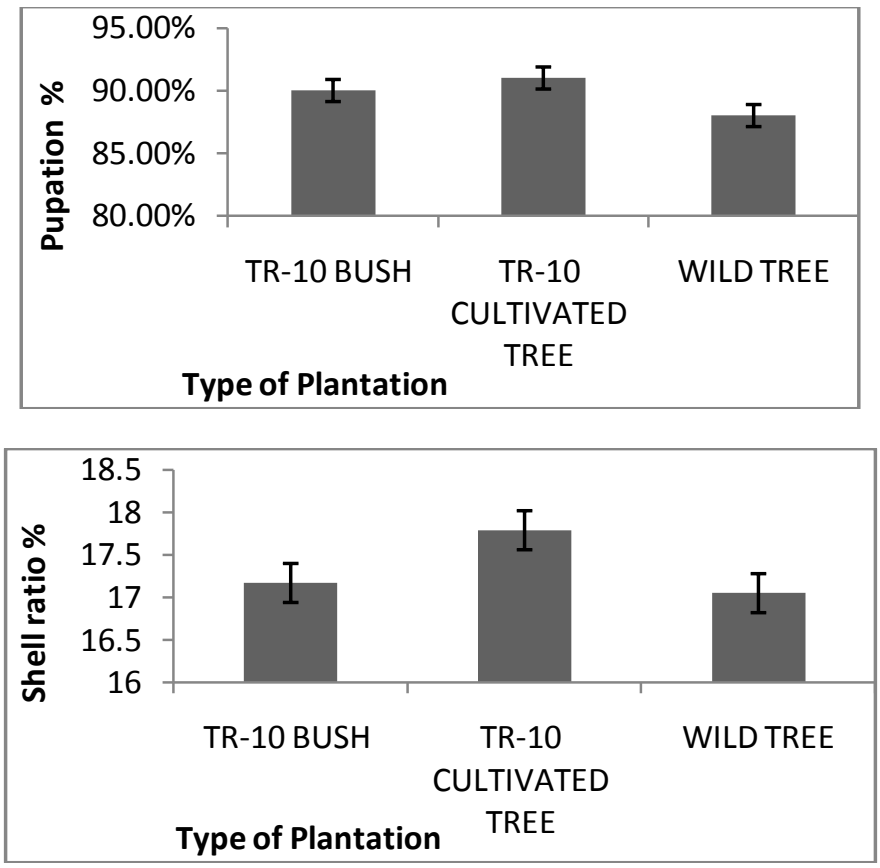

Figure 1:- Shows the effect of three plantation systems on the pupation percentage and shell ratio $\%$. Bar shows \pm standard deviation.

In case of Yield/ ten thousand larvae the value was highest in silkworms fed with cultivated tree followed by wild tree and bush tree. Although the yield in case of wild tree was also found to be high, this might be due to good rainfall during the period of rearing which rendered the leaves of wild tree with suitable moisture \% and has good moisture retention capacity. However, in general the leaves of wild trees are of bad quality with dust and pollutants due to road sides (Tariq et al. 2011). The rain helped to remove the dust etc and thus results are at par with bush and tree.

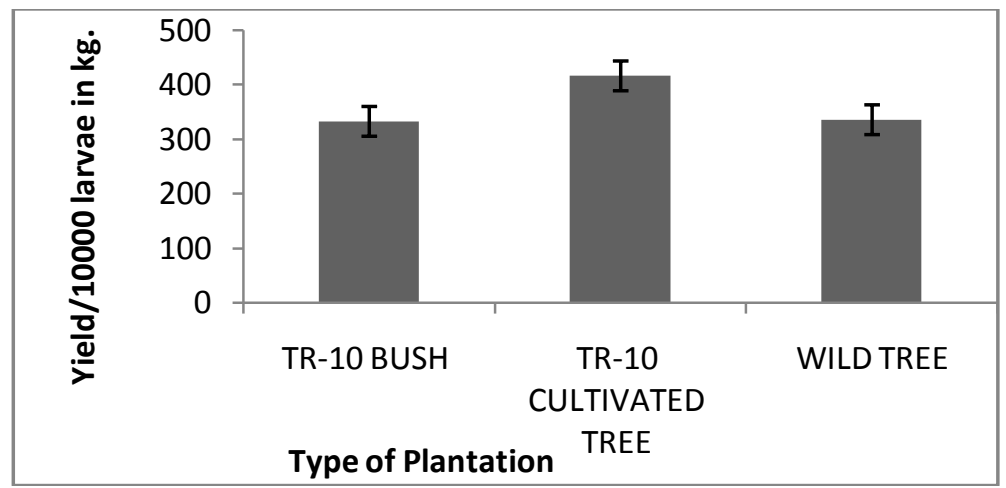

Fig. 2:- Shows Yield of Cocoons per 10,000 larvae. Bar shows \pm standard deviation.

Thus, we can conclude from the results obtained from the present investigation that the cultivated mulberry TR-10 variety should be grown for sericulture purpose in the Jammu region as these can be grown on the bunds and periphery of farmer's field. The farmers in this region do not have enough land and there are only two crops of 25 days in each season and hence bush type of plantation with closer spacing will not be suitable. Bush type of plantation will encroach their full land and they will not be able to take other crops whereas the cultivated tree on bunds/periphery besides providing them leaves for silkworm rearing in spring and autumn season also allow them to 
carry intercropping activities and will fetch them handsome additional income. On the other hand the wild tree of local variety should be discouraged as the leaves of local variety are poor in quality and huge wild trees will affect the intercropping pattern of farmers.

\section{Acknowledgement:-}

The authors are highly thankful to Joint Director RSRS Miran Sahib, Jammu for his valuable suggestions and providing lab facilities to conduct the present investigation.

\section{Refrences:-}

1. Aruga H. (1994): Principles of Sericulture. A. Balkema, Rotterdam , pp: 376.

2. Choudhary P.C., Shukla P., Chosh B. and Sengupta K. (1991): Effect of spacing, crown height and method of pruning on mulberry leaf yield, quality of cocoon yield. Indian Journal of Sericulture, 30(1): 46-53.

3. Gawade, B.V. and Medhe, N.K. (2010) Feeding effect of some mulberry varieties on larval weight of silkworm, Bombyx mori L. Green Farming. An Intl. J. Applied Agri. and Horticulture Sciences, 1(5): 545-546.

4. Krishnaswami, S. (1978) New Technology of Silkworm Rearing. Bulletin Sericulture No. 2, CSRTI, Mysore.

5. Liaw, G.J. (1991) Effectiveness of artificial diets prepared from different varieties and maturity of mulberry leaves on development of silkworm Bombyx mori L. China J. Entomol., 11(3): 260-263.

6. Machii and Katagiri. (1990): Varietal diiferences in food value of mulberry leaves with special reference to production efficiency of cocoon shell. Journal of Sericultural Science, 59(1):34-42.

7. Machii K. and Katagiri K. (1991): Varietal diiferences in nutritive values of mulberry leaves for rearing silkworms. Japan Agricultural Research Quarterly, 5:23-27.

8. Minamizawa K. (1997): Moriculture: The science of mulberry cultivation. CRC Press, Boca Raton, Florida, USA.

9. Miyashita V., 1986. A report on mulberry cultivation and trainings method suitable to Bivoltine rearing in Karnataka, CSB, Bangalore, India.

10. Sarkar A. and Fujita H. (1994): Better technique for nutritive evaluation of mulberry leaves for silkworm, Bombyx mori L. Indian Journal of Sericulture. 33:19-22.

11. Tariq A. Khan, Ramegowda G.K. and Dar M.Y. (2013). Effect of road dust pollution in mulberry on silkworm performance in Kashmir valley, India. Research Journal of Agricultural Sciences 4(4): 501-506.

12. Thangamani R. and Vivekanandan M. (1984). Physiological studies \& leaf nutrient analysis in the evaluation of best mulberry varieties. Sericologia, 24, 317-324. 